Eur. J. Clin. Chem. Clin. Biochem.

Vol. 29, 1991, pp. 493-498

(C) 1991 Walter de Gruyter \& Co.

Berlin - New York

\title{
Microalbuminuria in Diabetic Patients: Relationship to Lipid, Glyco-metabolic, Coagulation and Fibrinolysis Parameters
}

\author{
By J.W.J. van Wersch ${ }^{1}, S . H . J$. Donders $^{2}$, L. W. J. J. M. Westerhuis ${ }^{3}$ and W. J. R. R. Venekamp ${ }^{4}$
}

1 Haematological laboratory

2 Dept. of internal medicine

De Wever Hospital Heerlen, The Netherlands

${ }^{3}$ Clinical chemical laboratory

4 Dept. of internal medicine

St. Gregorius Hospital, Brunssum, The Netherlands

(Received January 14/June 6, 1991)

Summary: One hundred and sixteen insulin treated diabetic patients were evaluated for the relationship between the presence of microalbuminuria and several lipid, glyco-metabolic, coagulation and fibrinolysis factors. A significant correlation existed only between microalbuminuria and $\operatorname{HbA}_{1 \mathrm{c}}(\mathrm{r}=0.23, \mathrm{p}=0.008)$ and D-dimer $(r=0.28, p=0.002)$. After the subdivision of the patients in a group without $(n=85)$ and a group with microalbuminuria $(n=31)$ significant differences were found between these two groups for the HDL-cholesterol content $(\mathrm{p}<0.05)$, the $\mathrm{HbA}_{1 \mathrm{c}}$ level $(\mathrm{p}<0.01)$ and for the D-dimer concentration $(\mathrm{p}<0.01)$. Comparison of the patient groups without and with microalbuminuria separately with a healthy volunteers group without albuminuria resulted in significant differences for $\mathrm{HDL}$-cholesterol, triacylglycerols, $\mathrm{HbA}_{1 \mathrm{c}}$, fructosamine, fibrin monomer and D-dimer, whereas fibrinogen also was significantly different between the diabetic group without microalbuminuria and the healthy volunteers group. Several factors predisposing for atherosclerosis (decrease of $\mathrm{HDL}$-cholesterol, increase of triacylglycerols, coagulation activation with relatively insufficient fibrinolysis̄) wëre noticed in both diabetic groups without or with microalbuminuria, but more pronounced in the latter group. The appliance of a Receiver Operating Characteristic (ROC) curve for $\mathrm{HbA}_{1 \mathrm{c}}$ against microalbuminuria (cuf-off level $20 \mu \mathrm{g} / \mathrm{min}$ ) reconfirmed the value of adequate glycaemic control in diabetics for the prevention of microalbuminuria. In conclusion the results of this study show a significantly poorer glycaemic control in insulin treated diabetics with microalbuminuria than in those without microalbuminuria. The presence of lower HDL-cholesterol, higher triacylglycerols and the elevation of fibrin monomers and D-dimers is more pronounced in the microalbuminuria group. No direct correlation could however be found between the coagulation and fibrinolysis factors and the extent of microalbuminuria in the diabetic patient groups.

\section{Introduction}

The occurrence of microalbuminuria (1) is accepted as an early indicator of microangiopathy in diabetes mellitus i.e. diabetic nephropathy. The onset of the clinical symptoms of diabetic nephropathy may be preceded by a silent period of variable duration during which diabetic patients show only microalbuminuria
(2). This stage can be defined as the period in which the mean urinary albumin excretion rate is significantly higher $(20-200 \mu \mathrm{g} / \mathrm{min})$ than that in reference subjects (3). The clinical syndrome of diabetic nephropathy is characterised by persistent proteinuria (4), accompanied by increased morbidity and mortality in diabetic patients $(5-11)$. During the stage of 
clinical proteinuria and progressive renal failure, there are changes in the plasma lipoprotein concentration $(12-14)$ which are thought to contribute to the increased cardiovascular risk. Recently, in a case-control study (15), the concentrations of lipoproteins, apolipoproteins, fibrinogen and factor VII were compared in insulin-dependent diabetic patients with $(n=20)$ and without $(n=20)$ microalbuminuria under similar glyco-metabolic control $\left(\mathrm{HbA}_{1}\right)$.

In this study we have investigated the correlation between the microalbuminuria and the following parameters: several lipid fractions (cholesterol, HDLcholesterol, LDL-cholesterol, triacylglycerol); parameters for glyco-metabolic control $\left(\mathrm{HbA}_{\mathrm{ic}}\right.$ and fructosamine) $(16,17)$; the routine clotting test fibrinogen; sensitive indicators for clotting activation like fibrin monomers and the thrombin-antithrombin-III complex (18); and the fibrinolysis factors, plasminogen activator inhibitor $(19,20)$ and D-Dimer, the latter being a sensitive indicator of the onset of reactive fibrinolysis (21). The aim of the study was to investigate the possibility that biochemical parameters other than urinary microalbumin excretion rates possess predictive value for the occurrence of diabetic angiopathy.

\section{Materials and Methods}

Methods

The serum samples were analysed with a Cobas Bio centrifugal fast analyser and commercial test kits according to the manufacturer's instructions were used.

- Serum triacylglycerol:

Hoffmann La Roche, Basel, Switzerland, product No. 0710865

- total serum cholesterol:

Boehringer Mannheim, Germany, product no. 237574

- Serum HDL cholesterol:

Boehringer Mannheim, Germany, product No. 543004

- Serum LDL cholesterol: calculated by applying the Friedewald equation

- $\mathrm{HbA}_{\mathrm{ic}}$ in haemolysate:

Bio $\mathrm{Rad}$ ion exchange column chromatography, product No. $192-8001$

- Serum fructosamine: Hoffmann La Roche, Basel, Switzerland, product No. 0711217.

The test was performed according to the method of Johnson et al. (17) on a Cobas Bio centrifugal analyser

- Plasma D-Dimer:

For the Elisa D-dimer determinations we used the test kit of Boehringer Mannheim, product No. 998117. The measurements were carried out on the Bio Rad micro-titre reader system. The reactions were performed in polystyrene microtitre plates of the Nunc Corporation
- Plasma plasminogen activator inhibitor: Test kit of Kabi Vitrum COA-SET PAI.

- Plasma thrombin-antithrombin III:

Elisa test kit Enzygnost-TAT, Behring, Hoechst, Marburg (Germany), product No. OURC 10/11

- Fibrinogen: i Turbidimetric method of Behring, using the CTS-fibrinogen reagent on the Chromotime System (Behring).

- Fibrin monomers: chromogenic COA-set FM test Kabi Vitrum Diagnostica.

- Urinary microalbumin: immunoturbidimetric test of Orion Diagnostica Corporation, product No. 67352

\section{Patients}

One hundred and sixteen insulin-treated diabetic patients, consisting of 47 males (mean age 55.3 years, range $20-80$ ) and 69 females (mean age 60.1 years, range $30-82$ ) were included in the study. The percentage of patients with microalbuminuria (i. e. $20-200 \mu$ g urinary albumin excreted per min) was $26.7 \%$. Patients with a urinary albumin excreeding $200 \mu \mathrm{g}$ per min were excluded from the study. The co-medication of the patients included in the study consisted mainly of oral anticoagulants or acetyl-salicylic acid. Patients treated with antihypertensive drugs or corticosteroids were excluded. The number of true type 1 subjects was 62 , equally divided between the two albumin excretion groups. The general characteristics of the patients are given in table 1. Retinopathy was diagnosed by fundoscopy and fluorescence angiography. Neuropathy was diagnosed by measurement of the vibration sense and the presence of sensory disturbance in the extremities. Blood samples were collected when the patients attended the hospital (St. Gregorius hospital, Brunssum, The Netherlands) for their routine diabetic control in the department for internal medicine. The reference values were obtained from 50 subjectively healthy individuals, ranging in age from 24 to 50 years. Reference ranges were taken to be the mean values \pm 2 SD.

\section{Samples}

We collected venous blood samples between 8.30 and $9.00 \mathrm{a}$. m. and prepared citrated plasma by centrifugation of nine volumes of freshly drawn blood with one volume of trisodium citrate $(0.11 \mathrm{~mol} / \mathrm{l})$ for $30 \mathrm{~min}$ at $25^{\circ} \mathrm{C}(1600 \mathrm{~g})$. The plasma was used immediately or stored at $-70^{\circ} \mathrm{C}$ in plastic tubes and thawed with tap water for $5 \mathrm{~min}$ before use. For the glyco-metabolic determinations washed red cells were haemolysed and the haemolysate as such was used for the chromatographic separation of $\mathrm{HbA}_{1 \mathrm{c}}$. Urine samples for urinary albumin determination were obtained from a morning portion after collecting overnight, and the time of collection was recorded.

\section{Statistics}

Correlations between the different parameters and urinary microalbumin were investigated by the Spearman rank test. The significance of the differences was assessed' by the Mann-Whitney-Wilcoxon test. The sensitivity and specificity of $\mathrm{HbA}_{1 \mathrm{c}}$ and $\mathrm{D}$-dimer were calculated according to the presence or absence of microalbuminuria as the decision standard (cut-off level $20 \mu \mathrm{g} / \mathrm{min}$ ). Receiver Operating Characteristic (ROC) curves for assessing the power of the tests were constructed as described earlier (22). 
Tab. 1. General characteristics of the patients according to the albumin excretion rate. Values are means (SD). The number of the patients with retinopathy, and neuropathy are given as percentages.

\begin{tabular}{|c|c|c|c|c|c|}
\hline \multirow[b]{2}{*}{$\begin{array}{l}\text { Age (years) } \\
\text { Body mass index } \\
\text { Diastolic pressure } \\
\text { Systolic pressure } \\
\text { Duration of diabetes } \\
\text { Serum creatinine }\end{array}$} & \multirow[b]{2}{*}{$\begin{array}{l}\left(\mathrm{kg} / \mathrm{m}^{2}\right) \\
(\mathrm{mmHg}) \\
(\mathrm{mmHg}) \\
\text { (years) } \\
(\mu \mathrm{mol} / \mathrm{l})\end{array}$} & \multicolumn{2}{|c|}{$\begin{array}{l}\text { Diabetic patients } \\
\text { with albumin excretion rate } \\
\leqslant 20 \mu \mathrm{g} / \mathrm{min} \text {; } \\
\text { mean } 9.7 \text {, range } 0-20 \\
(\mathrm{n}=85)\end{array}$} & \multicolumn{2}{|c|}{$\begin{array}{l}\text { Diabetic patients } \\
\text { with albumin excretion rate } \\
20-200 \mu \mathrm{g} / \text { min; } \\
\text { mean } 47.0 \text {, range } 21-142 \\
(\mathrm{n}=31)\end{array}$} \\
\hline & & $\begin{array}{c}55.3 \\
24.3 \\
83 \\
128 \\
14.0 \\
82.1\end{array}$ & $\begin{array}{r}(16.1) \\
(3.5) \\
(6.9) \\
(10.4) \\
(8.7) \\
(12.0)\end{array}$ & $\begin{array}{c}60.1 \\
24.1 \\
85 \\
128 \\
14.5 \\
82.1\end{array}$ & $\begin{array}{l}(14.8) \\
(4.6) \\
(8.1) \\
(15.8) \\
(9.7) \\
(15.8)\end{array}$ \\
\hline $\begin{array}{l}\text { Retinopathy } \\
\text { Neuropathy }\end{array}$ & & \multicolumn{2}{|c|}{$\begin{array}{r}15.3 \% \\
7.1 \%\end{array}$} & \multicolumn{2}{|l|}{$\begin{array}{l}29.0 \% \\
12.9 \%\end{array}$} \\
\hline
\end{tabular}

\section{Results}

The Spearman rank collection between urinary microalbumin concentrations and several biochemical parameters is given in table 2 . Significant correlations with microalbuminuria were found only for $\mathrm{HbA}_{1 \mathrm{c}}$ and $D$-dimer, with $r$ values of $0.232(p=0.008$ and $0.278(p=0.002)$ respectively. In table 3 the diabetic patient groups without $(\leqslant 20 \mu \mathrm{g} / \mathrm{min})$ and with $(>20$ $\mu \mathrm{g} / \mathrm{min}$ ) albuminuria are compared with a healthy volunteers group without albuminuria. No significant differences for either diabetic group were found for cholesterol, cholesterol/HDL-cholesterol ratio, LDLcholesterol, thrombin-antithrombin III complex and plasminogen activator inhibitor. Additionally, fibrinogen levels were not significantly altered in the group with a high albumin excretion rate. The other parameters showed highly significant differences between the two patient groups and the volunteer group. $\mathrm{Mu}$ tual comparison of the two patient groups as given in table 4 showed a significant decrease for HDL-

Tab. 2. Spearman rank correlation between urinary microàlbumin and several biochemical parameters in diabetic patients.

\begin{tabular}{lrl}
\hline $\begin{array}{l}\text { Microalbumin } \\
\text { versus } \\
\text { parameter }\end{array}$ & $\mathrm{r}$ & $\mathrm{p}$ \\
\hline Cholesterol & & \\
Cholesterol/HDL-cholesterol ratio & 0.04 & 0.65 \\
HDL-cholesterol & 0.01 & 0.26 \\
LDL-cholesterol & -0.14 & 0.11 \\
Triacylglycerols & 0.03 & 0.79 \\
HbA & 0.13 & 0.14 \\
Fructosamine & 0.23 & 0.008 \\
Fibrinogen & 0.07 & 0.42 \\
Fibrin monomers & 0.18 & 0.06 \\
Thrombin-antithrombin-III & 0.13 & 0.17 \\
Plasminogen activator inhibitor & 0.11 & 0.23 \\
D-Dimer & 0.05 & 0.60 \\
& 0.28 & 0.002 \\
\hline
\end{tabular}

cholesterol $(p<0.05)$, and significant increases for $\mathrm{HbA}_{1 \mathrm{c}}(\mathrm{p}<0.01)$ and D-dimer $(\mathrm{p}<0.01)$.

To assess the predictive power of the $\mathrm{HbA}_{1 \mathrm{c}}$ in relation to the microalbuminuria, a ROC-curve (fig. 1) was calculated at different cut-off levels of the test against microalbuminuria as the reference parameter at the cut-off decision level $20 \mu \mathrm{g} / \mathrm{min}$. For the $\mathrm{HbA}_{1 \mathrm{c}}$ range from $6 \%$ to $12 \%$ the sensitivity ranged from $38 \%$ to $100 \%$, the specificity from $85 \%$ to $65 \%$.

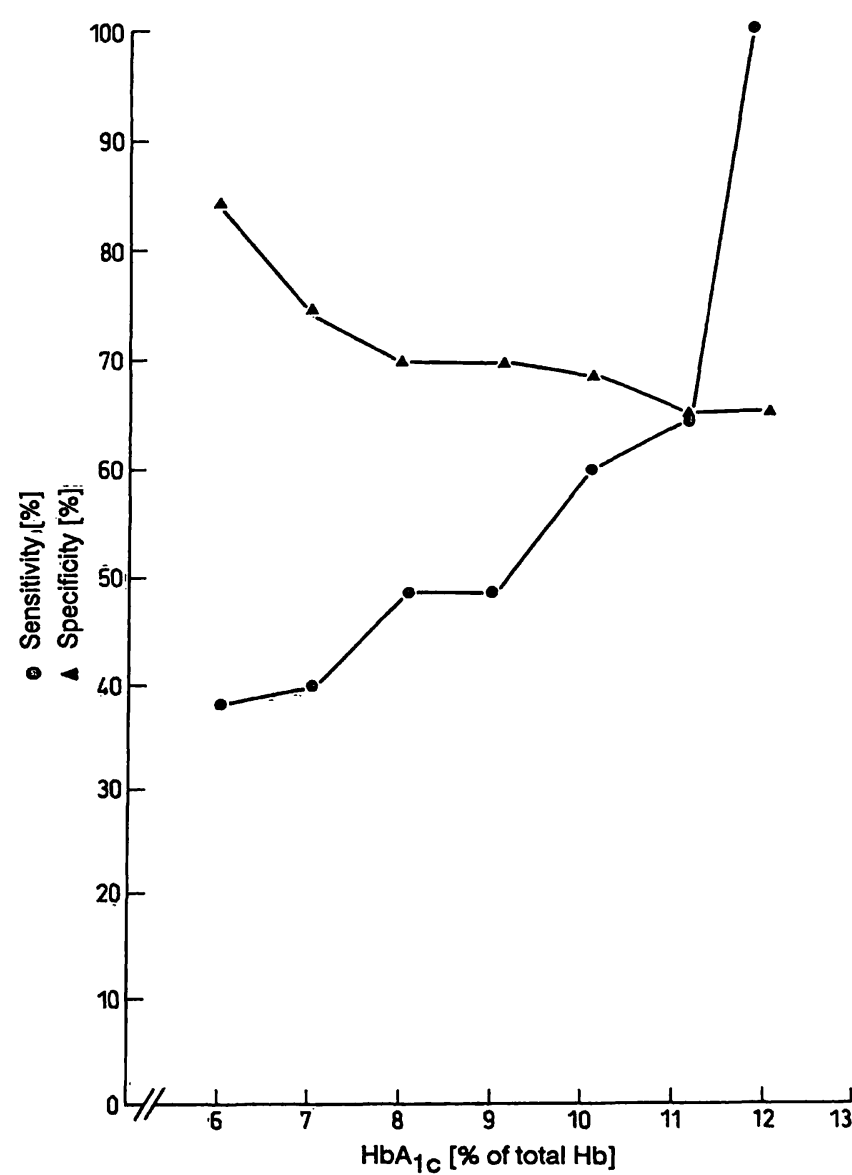

Fig. 1. Sensitivity ( $(\bullet)$ and specificity $(\mathbf{\Delta})$ at different $\mathrm{HbA}_{\mathrm{l}}$ decision levels (reference cut-off parameter : urinary microalbumin $20 \mu \mathrm{g} / \mathrm{min})$. 
Tab. 3. Comparison of the healthy volunteers (group 1) with the two diabetic groups with (group 3) and without (group 2) microalbuminuria (Mann-Whithey-Wilcoxon test).

\begin{tabular}{|c|c|c|c|c|c|c|c|c|c|}
\hline \multirow[b]{4}{*}{ Variables } & & \multicolumn{8}{|c|}{ Albumin excretion rate } \\
\hline & & \multirow{2}{*}{\multicolumn{2}{|c|}{$\begin{array}{l}\leqslant 20 \mu \mathrm{g} / \mathrm{min} \\
\text { Group of healthy } \\
\text { volunteers } \\
\text { Group 1 } \\
(\mathrm{n}=50)\end{array}$}} & \multirow{2}{*}{\multicolumn{2}{|c|}{$\begin{array}{l}\leqslant 20 \mu \mathrm{g} / \mathrm{min} \\
\text { Diabetics } \\
\text { Group } 2 \\
(\mathrm{n}=85)\end{array}$}} & \multicolumn{2}{|c|}{$20-200 \mu \mathrm{g} / \mathrm{min}$} & \multirow{2}{*}{\multicolumn{2}{|c|}{$\begin{array}{l}\text { Significance level: } \\
\text { p-value }\end{array}$}} \\
\hline & & & & & & \multicolumn{2}{|c|}{$\begin{array}{l}\text { Group } 3 \\
(n=31)\end{array}$} & & \\
\hline & & Mean & (SD) & Mean & (SD) & Mean & (SD) & $\mathrm{G} 2 / \mathrm{G} 1$ & G3/G1 \\
\hline Cholesterol & $(\mathrm{mmol} / \mathrm{l})$ & 5.8 & $(0.9)$ & 6.2 & $(1.5)$ & 6.0 & (1.4) & n.s. & n.s. \\
\hline $\begin{array}{l}\text { Cholesterol/HDL- } \\
\text { cholesterol }\end{array}$ & ratio & 5.3 & $(0.9)$ & 5.2 & $(2.0)$ & 6.0 & $(2.7)$ & n.s. & n.s. \\
\hline HDL-cholesterol & $(\mathrm{mmol} / \mathrm{l})$ & 1.5 & $(0.13)$ & 1.27 & $(0.44)$ & 1.1 & $(0.3)$ & $<0.001$ & $<0.0001$ \\
\hline LDL-cholesterol & $(\mathrm{mmol} / \mathrm{l})$ & 4.0 & $(0.5)$ & 3.9 & $(1.2)$ & 3.9 & $(1.1)$ & n.s. & n.s. \\
\hline Triacylglycerols & $(\mathrm{mmol} / \mathrm{l})$ & 1.4 & $(0.3)$ & 2.49 & $(2.80)$ & 2.24 & $(1.31)$ & $<0.01$ & $<0.0001$ \\
\hline $\mathrm{HbA}_{\mathrm{lc}}$ & $(\%)$ & 5.5 & $(0.75)$ & 7.9 & $(1.6)$ & 8.8 & $(1.9)$ & $<0.0001$ & $<0.0001$ \\
\hline Fructosamine & $(\mathrm{mmol} / \mathrm{l})$ & 2.9 & $(0.3)$ & 2.2 & $(0.6)$ & 3.5 & $(0.8)$ & $<0.0001$ & $<0.0001$ \\
\hline Fibrinogen : . & $(\mathrm{g} / \mathrm{l})$ & 3.8 & $(0.3)$ & 3.4 & $(0.8)$ & 3.7 & $(1.2)$ & $<0.01$ & n. s. \\
\hline Fibrin monomer & $(\mathrm{nmol} / \mathrm{l})$ & 10.8 & $(1.2)$ & 13.9 & $(0.4)$ & 13.7 & $(5.2)^{\circ}$ & $<0.0001$ & $<0.0001$ \\
\hline $\begin{array}{l}\text { Thrombin- } \\
\text { antithrombin-III }\end{array}$ & $(\mu \mathrm{g} / \mathrm{l})$ & 2.6 & $(0.8)$ & 4.4 & (11.8) & 5.6 & $(10.8)$ & n.s. & n.s. \\
\hline $\begin{array}{l}\text { Plasminogen } \\
\text { activator inhibitor }\end{array}$ & $\left(10^{3} \mathrm{AU} / \mathrm{l}\right)$ & 12.7 & $(6.3)$ & 14.8 & (11.1) & 18.3 & (11.4) & n. s. & n.s. \\
\hline D-Dimer & $(\mu \mathrm{g} / \mathrm{l})$ & 238 & (100) & 412 & (356) & 567 & (468) & $<0.0001$ & $<0.0001$ \\
\hline
\end{tabular}

Tab. 4. Mutual comparison of the diabetic groups without (group 1) and with (group 2) microalbuminuria (Mann-WhitneyWilcoxon test).

\begin{tabular}{|c|c|c|c|c|c|c|c|}
\hline \multirow[t]{2}{*}{ Diabetics } & & \multicolumn{4}{|c|}{ Albumin excretion rate } & & \\
\hline & & \multicolumn{2}{|c|}{$\leqslant 20 \mu \mathrm{g} / \mathrm{min}$} & \multicolumn{3}{|c|}{$20-200 \mu \mathrm{g} / \mathrm{min}$} & \\
\hline \multirow[t]{2}{*}{ Variable } & & Group 2 & & Group 3 & & & $\begin{array}{l}\text { Significance level: } \\
\text { p-value }\end{array}$ \\
\hline & - & $\overline{\mathrm{x}}(\mathrm{SD})$ & & $\overline{\mathrm{x}}(\mathrm{SD})$ & & & \\
\hline Cholesterol & $(\mathrm{mmol} / \mathrm{l})$ & 6.2 & $(1.5)$ & 6.0 & $(1.4)$ & & n.s. \\
\hline $\begin{array}{l}\text { Cholesterol/HDL- } \\
\text { cholesterol ratio }\end{array}$ & & 5.2 & $(2.0)$ & 6.0 & (2.7) & & n.s. \\
\hline HDL-cholesterol & $(\mathrm{mmol} / \mathrm{l})$ & 1.27 & $(0.44)$ & 1.1 & $(0.3)$ & & $<0.05$ \\
\hline LDL-cholesterol & $(\mathrm{mmol} / \mathrm{l})$ & 3.9 & $(1.2)$ & 3.9 & (1.1) & & n.s. \\
\hline Triacylglycerols & $(\mathrm{mmol} / \mathrm{l})$ & 2.49 & $(2.80)$ & 2.24 & $(1.31)$ & & n.s. \\
\hline $\mathrm{HbA}_{1 \mathrm{c}}$ & $(\%)$ & 7.9 & (1.6) & 8.8 & (1.9) & & $<0.01$ \\
\hline Fructosamine & $(\mathrm{mmol} / \mathrm{l})$ & 3.3 & $(0.6)$ & 3.5 & $(0.8)$ & & n.s. \\
\hline Fibrinogen & $(\mathrm{g} / \mathrm{l})$ & 3.4 & $(0.8)$ & 3.7 & $(1.2)$ & & n.s. \\
\hline Fibrin monomer & $(\mathrm{nmol} / \mathrm{l})$ & 13.9 & $(4.9)$ & 13.7 & $(5.2)$ & & n.s. \\
\hline $\begin{array}{l}\text { Thrombin- } \\
\text { antithrombin III }\end{array}$ & $(\mu \mathrm{g} / \mathrm{l})$ & 4.4 & $(11.8)$ & 5.6 & $(10.8)$ & & n.s. \\
\hline $\begin{array}{l}\text { Plasminogen } \\
\text { activator inhibitor }\end{array}$ & $\left(10^{3} \mathrm{AU} / \mathrm{l}\right)$ & 14.8 & (11.1) & 18.3 & (11.4) & & n.s. \\
\hline D-Dimer & $(\mu \mathrm{g} / \mathrm{l})$ & 412 & (356) & 567 & (468) & $\because$ & $<0.01$ \\
\hline
\end{tabular}




\section{Discussion}

The general characteristics of the studied diabetic population, as shown in table 1 , contain data that need some clarification. The reported mean values for blood pressure and urinary albumin excretion in patients with a mean duration of diabetes mellitus of 14 years indicate, as mentioned in the patients section, that patients with hypertension and "macroalbuminuria" were excluded from the study. Possibly therefore we found no differences in mean systolic and diastolic blood pressure between the diabetic patients with and without microalbuminuria. The correlation between microalbuminuria and several biochemical parameters was shown to be significant only for $\mathrm{HbA}_{1 \mathrm{c}}$ and D-dimer (tab. 2). These results suggest an increased prevalence of microalbuminuria associated with poorer glycaemic control and augmented reactive fibrinolysis (probably after preceding coagulation activation). Recently, we described an increase of coagulation activation with a decreased efficiency of glyco-metabolic control (23), as well as a relative decrease of the elevated reactive fibrinolysis with increasing $\mathrm{HbA}_{1 \mathrm{c}}(24)$ in a large population of insulindependent diabetic patients. Thus, the D-dimer level might be an indirect indicator of long term sequelae of diabetes mellitus such as microalbuminuria.

Comparison of the insulin-dependent diabetics with or without microalbuminuria with a group of healthy individuals showed significant alterations in some lipid parameters (HDL-cholesterol, triacylglycerol) and in some coagulation and fibrinolysis parameters (fibrin monomer, D-dimer). Several factors might be responsible for the differences between the three groups, but most probable is the influence of the glycaemic control. In young insulin-dependent diabetics, the glyço-metabolic control state has been shown to influence the lipoprotein serum concentrations $(25-27)$ as well as the prevalence of microalbuminuria, whereas changes in the lipid fractions have been described in diabetics with microalbuminuria and with poor glycaemic control (13).

Recently triacylglycerol has been reported to enhance the activation of coagulation factor. VII (28), leading to thrombin formation and hence to fibrin monomer formation and reactive fibrinolysis (D-dimers). Because șerum triacylglycerol correlates with plasminogen activator inhibitor, fibrinolysis might be impaired when triacylglycerol is elevated (29). Moreover increased serum triacylglycerol as well as elevated plasminogen activator inhibitor levels have been observed to be strongly related to an enhanced risk of ischaemic heart disease $(30-34)$. The two diabetic groups of the present study differ from the reference group with respect to those parameters known to be correlated with an enhanced risk of cardiovascular disease. In the mutual comparison of the two diabetic patient groups with and without microalbuminuria (tab. 4) the HDL-cholesterol concentration, a known risk factor for cardiovascular disease, was significantly decreased in the microalbuminuria group. Moreover, there appeared to be an enhanced clotting activation (fibrin monomers) with reactive fibrinolysis (D-dimer) in both diabetic groups, whereas $\mathrm{HbA}_{1 \mathrm{c}}$ was higher in the microalbuminuria group, indicating poorer glycaemic control. In view of the relative decrease of the fibrinolysis level with increasing $\mathrm{HbA}_{1 \mathrm{c}}$ which we reported earlier (24), there might, however, be insufficient reactive fibrinolysis for the extent of the signalized coagulation activation. For the testing of the power of $\mathrm{HbA}_{1 \mathrm{c}}$ as a predictive parameter for microalbuminuria we constructed a ROC curve for $\mathrm{HbA}_{1 \mathrm{c}}$ at different cut-off levels. The ROC curve showed $100 \%$ sensitivity for the prediction of microalbuminuria ( $>20 \mu \mathrm{g} / \mathrm{min}$ ) at a cut-off level of $12 \% \mathrm{HbA}_{1 \mathrm{c}}$. Moreover, it should be noted that between $11 \%$ and $12 \% \mathrm{HbA}_{1 \mathrm{c}}$ there is a jump in the prediction sensitivity from 66.7 to $100 \%$; which might be another indication for setting the goal of glycaemic control at least below the value of $11 \% \mathrm{HbA}_{1 \mathrm{c}}$. Nevertheless it seems worthwile from the course of the ROC curve to pursue a normoglycaemia, because in that range a decrease of the sensitivity is achievable from $66.7 \%$ (at a $\mathrm{HbA}_{1 \mathrm{c}}$ level of $11 \%$ ) to $37.8 \%$ (at a $\mathrm{HbA}_{1 \mathrm{c}}$ level of $6 \%$ ). This finding agrees with the results of Klein et al. (35), who demonstrated a strong and consistent relation between hyperglycaemia and the incidence and progression of retinopathy, and who emphasized the importance of normoglycaemia in diabetics.

\section{Conclusion}

The results of this study show that in insulin-treated diabetics with microalbuminuria glycaemic control is significantly poorer than in the patients without microalbuminuria. Several abnormalities are significantly more pronounced in the microalbuminuria than in the non-microalbuminuria group; the lipid fractions contain lower HDL-cholesterol and higher triacylglycerol, which are prerequisites for the development of atherosclerosis. Of the coagulation and fibrinolysis factors, the elevation of the fibrin monomer and the D-dimer values should be noted, because they indicate an activation of coagulation, possibly with relatively insufficient reactive fibrinolysis in poor glycaemic control, thereby possibly also constituting risk factors for coronary heart disease. We did not, however, observe a direct correlation between coagulation and fibrinolysis and the existence of microalbuminuria in the diabetic patient groups. 


\section{References}

1. Viberti, G. C., Jarret, R. J., Mahmud, U., Hill, R. D. Argyropoulus, A. \& Keen, H. (1982) Microalbuminuria as a predictor of clinical nephropathy in insulin dependent diabetes mellitus. Lancet $I, 1430-1432$.

2. Feldt-Rasmussen, B. \& Mathiesen, E. R. (1984) Variability of urinary albumin excretion in incipient diabetic nephropathy. Diabetic Nephropathy 3, 101-103.

3. Mogensen, C. E., Christensen, C. K. \& Vitinghus, E. (1983) The stages in diabetic renal disease with emphasis on the stage of incipient diabetic nephropathy. Diabetes 32 (suppl. 2), 64-78.

4. Borch-Johnsen, K. \& Kreiner, S. (1987) Proteinuria: a predictor of cardiovascular mortality in insulin-dependent diabetes mellitus. Br. Med. J. 294, 1651-1654.

5. Mc Crary, R. F., Pitts, T. O. \& Puschett, J. B. (1981) Diabetic nephropathy. Natural course, survivorship and therapy. Am. J. Nephrol. 1, 206-218.

6. Andersen, A. R., Christiansen, J. S., Andersen, J. K., Kreiner, S. \& Deckert, T. (1983) Diabetic nephropathy in type 1 (insulin-dependent) diabetes: an epidemiological study. Diabetologia 2, 496-501.

7. Borch-Johnson, K., Andersen, P. K. \& Deckert, T. (1985) The effect of proteinuria on relative mortality in type 1 (insulin-dependent) diabetes mellitus. Diabetologia 28, 590-596.

8. Krolewski, A. S., Kosinski, E. J., Warram, J. H., Leland, O. S., Busick, E. J., Asmal, A. C., Rand, L. I., Christlieb, A. R., Bradley, R. F. \& Kahn, C. R. (1987) Magnitude and determinants of coronary artery disease in juvenile-onset, insulin-dependent diabetes mellitus. Am. J. Cardiol. 59, $750-755$.

9. Mogensen, C. E. (1984) Microalbuminuria predicts clinical proteinuria and early mortality in maturity onset diabetes. N. Engl. J. Med. 310, 356-360.

10. Jarrett, R. J., Viberti, G. C., Argyropoulus, A., Hill, R. D., Mahmud, U. \& Murrells, T. J. (1984) Microalbuminuria predicts mortality in non-insulin dependent diabetes. Diabetic Med. 1, 17-19.

11. Matlock, M. B., Keen, H., Viberti, G. C., El Gohari, M. R., Murrells, T. J., Scott, G. S., Wing, J. R. \& Jackson, P. G. (1988) Coronary heart disease and urinary albumin excretion rate in type II (non-insulin-dependent) diabetic patients. Diabetologia $31,82-87$.

12. Winocour, P. H., Durrington, P. N., Ishola, M., Anderson, D. C. \& Cohen, H. (1987) Influence of proteinuria on vascular disease, blood pressure and lipoproteins in insulin dependent diabetes mellitus_Br. Med. J. 294, 1648-1651.

13. Jensen, T., Stender, S. \& Deckert, T. (1988) Abnormalities in plasma concentrations of lipoproteins and fibrinogen in type I (insulin-dependent) diabetic patients with increased urinary albumin excretion. Diabetologia 31, 142-145.

14. Vannini, P., Ciavarella, A., Flammini, M., Bargossi, A. M., Forlani, G., Borgnino, L. C. \& Orsino, G. (1984) Lipid abnormalities in insulin dependent diabetic patients with albuminuria. Diabetes Care 7, 151-154.

15. Jones, S. L., Close, C. F., Matlock, M. B., Jarrett, R. J., Keen, H. \& Viberti, G. C. (1989) Plasma lipid and coagulation factor concentrations in insulin dependent diabetics with microalbuminuria. Br. Med. J. 298, 487-490.

16. Miedema, K. \& Casparie, T. (1984) Glycosylated haemoglobins: biochemical evaluation and clinical utility (review). Ann. Clin. Biochem. 21, 2-15.

17. Johnson, R. N., Metcalf, P. A. \& Baker, J. R. (1982) Fructosamine: a new approach to the estimation of serum glycosylation. An index of diabetic control. Clin. Chim. Acta 127, 87-95.

18. Pelzer, H., Egbring, R., Seitz, R., Blanke, H. \& Heimburger, N. (1987) Thrombin-antithrombin III complex: a new parameter for detection of thrombotic states. Thromb. Haem. 58 (suppl) 237.

19. Hamsten, A., Waldins, G., Szamosi, A., Blombäck, M., De Faire, U., Dahlen, G., Landon, C. \& Wiman, B. (1987)
Plasminogen activator inhibitor in plasma: risk factor for recurrent myocardial infarction. Lancet $I I, 3-9$.

20. Wiman, B., Ljundberg, B., Chmielewska, J., Urden, G., Blombäck, M. \& Johnson, H. (1985) The role of the fibrinolytic system in deep vein thrombosis. J. Lab. Clin. Med. $105,265-270$.

21. Hunt, F. A., Rylatt, D. B., Hart, R. A. \& Bundesen, P. G (1985) Serum crosslinked fibrin (XDP) and fibrinogen/ fibrin degradation products (FDP) in disorders associated with activation of the coagulation or fibrinolytic systems. Br. J. Haematol. 60, 715-722.

22. Bick, J. R. \& Schultz, E. K. (1986) The use of relative operating characteristic (ROC) curves in the performance evaluation. Arch. Pathol. Lab. Med. 110, 13-20.

23. van Wersch, J. W. J., Westerhuis, L. W. J. J. M. \& Venekamp, W. J. R. R. (1990) On coagulation activation in diabetes mellitus. Haemostasis 20, 263-269.

24. van Wersch, J. W. J., Westerhuis, L. W. J. J. M. \& Venekamp, W. J. R. R. (1990) Glycometabolic control and fibrinolysis in diabetic patients. Haemostasis $20,241-250$.

25. Pietri, A., Dunn, F. L. \& Raskin, P. (1980) The effect of improved diabetic control on plasma lipid and lipoprotein levels. A comparison of conventional therapy and continuous subcutaneous insulin infusion. Diabetes 29, 10011005.

26. Tamborlane, W. V., Sherwin, R. S., Genel, M. \& Relig, P. (1979) Restoration of normal lipid and aminoacid metabolism in diabetic patients treated with a portable insulininfusion pump. Lancet $I, 1258-1261$.

27. Lopes-Virella, M. F., Wohltmann, H. J., Loadholt, C. B. \& Buse, M. G. (1981) Plasma lipids and lipoproteins in young insulin-dependent diabetic patients: relationship with control. Diabetologia 21, 216-223.

28. Nordøy, A., Illingworth, D. R., Connor, W. E. \& Goodnight, S. (1990) Increased activity of factor VII and factor VII-phospholipid complex measured using a Normotest system in subjects with hyperlipidemia. Haemostasis 20 , $65-72$.

29. Vague, P., Juhan-Vague, I., Aillaud, M. F., Baider, C., Viard, R., Alessi, M. C. \& Collen, D. (1986) Correlation between blood fibrinolytic activity, plasminogen activator inhibitor level, plasma insulin levè̀ añd relative body weight in normal and obese subjects. Metabolism 35, 250 .

30. Miller, M. E., Anagnostou, A., Ley, B., Marshall, P. \& Steiner, M. (1987) Effect of fish oil concentration on hemorrheological and hemostatic aspects of diabetes mellitus: a preliminary study. Thromb. Res. 47, $201-214$.

31. Carlson, L. A. \& Böttiger, L. E. (1972) Ischaemic heart disease in relation to factual values of plasma triglycerides and cholesterol. Lancet $I, 865-868$.

32. Aberg, H., Lithell, H., Selinus, I. \& Hedstrand, H. (1985) Serum triglycerides are a risk factor for myocardial infarction but not for angina pectoris. Results from a 10-year follow-up of Uppsala primary preventive study. Atherosclerosis 54, 89-97.

33. Páramo, J. A., Colucci, M. \& Collen, D. (1985) Plasminogen activator inhibitor in the blood of patients with coronary artery disease. Br. Med. J. 291, 573.

34. Mehta, J., Mehta, P., Lawson, D. \& Saldeen, T. (1987) Plasma tissue pläsminogen activator inhibitor levels in coronary artery disease: correlation with age and serum triglyceride concentrations. J. Amer. Coll. Cardiol. 9, 263.

35. Klein, R., Klein, B. E. K., Moss, S. E., Davis, M. D. \& DeMets, D. L. (1988) Glycosylated hemoglobin predicts the incidence and progression of diabetic retinopathy. $\mathrm{J}$. Am. Med. Ass. 260, 2864-2871.

Dr. J. W. J. van Wersch

Hoofd Haematologisch Lab.

De Wever Ziekenhuịs Heerlen

Postbus 4446

NL-6401 CX Heerlen 